(c) American Dairy Science Association, 2003.

\title{
Effects of Supplemental Energy on Metabolic and Immune Measurements in Periparturient Dairy Cows with Johne's Disease
}

\author{
J. R. Stabel, ${ }^{1}$ J. P. Goff, ${ }^{2}$ and K. Kimura ${ }^{2}$ \\ USDA-ARS, National Animal Disease Center, \\ ${ }^{1}$ Bacterial Diseases of Livestock Research Unit, \\ ${ }^{2}$ Periparturient Diseases of Cattle Research Unit, Ames, IA 50010
}

\begin{abstract}
The present study was designed to evaluate whether feeding supplemental energy would improve the metabolic profile and alleviate some of the immunosuppression typically noted during the periparturient period in dairy cows with Johne's disease. Twelve dairy cows naturally infected with Mycobacterium paratuberculosis were fitted with rumen cannulas in late gestation and assigned to treatment groups: control, $\mathrm{n}=6$; or stuffed, $n=6$. Cows in the control group were allowed to consume feed ad libitum. Cows assigned to the stuffed treatment group were also fed ad libitum but received additional total mixed rations by manually stuffing their rumens with refused feed to maintain dry matter intake of $2 \%$ body weight per day before calving and $2.5 \%$ body weight per day after calving. Serum nonesterified fatty acid levels were significantly decreased in stuffed cows compared with control cows, indicating that stuffing to maintain dry matter intake improved the energy balance in the cows. In addition, periparturient serum calcium and magnesium concentrations were significantly higher in stuffed cows. Stuffing modulated cell-mediated immunity by reducing lymphocyte proliferative responses to T-cell mitogens during early lactation. Stuffing resulted in an increase in the secretion of in vitro immunoglobulin by peripheral blood mononuclear cells after parturition when compared to control cows. These data demonstrate that energy balance is improved by providing additional energy in this manner and suggest energy supplementation can improve some aspects of immune function during the periparturient period.
\end{abstract}

(Key words: parturition, dairy cow, energy, Johne's disease)

Received November 26, 2002.

Accepted May 2, 2003.

Corresponding author: J. R. Stabel; e-mail: jstabel@nadc.ars. usda.gov.

\begin{abstract}
Abbreviation key: ConA = concanavalin A, HEYM = Herrold's egg yolk medium, PBMC = peripheral blood mononuclear cells, PHAP = phytohemagglutin P, PWM $=$ pokeweed mitogen.
\end{abstract}

\section{INTRODUCTION}

Paratuberculosis (Johne's disease) is associated with a long latent period of infection before clinical signs of disease develop. Stressors such as parturition, lactation, parasites, and concomitant infections with other pathogens can cause progression from subclinical to clinical disease in infected animals. Innate immune responses such as neutrophil and macrophage function are reduced around calving. In addition, $\mathrm{T}$ and $\mathrm{B}$ cell function are also significantly suppressed (Guidry et al., 1976; Kehrli et al., 1989a, 1989b; Saad et al., 1989). Immunosuppression associated with the periparturient period may affect the ability of a cow to resist new infections that can occur at this time or, in the case of paratuberculosis, to control chronic subclinical infections that have remained latent for some time. A reduction in host immunity may allow an infection previously held in check to progress to clinical disease. Several factors may influence the degree of immunosuppression at calving, including changes in nutrition, elevations in cortisol levels, and reproductive hormone fluctuations (Guidry et al., 1976; Kehrli et al., 1999; Waller, 2000). Metabolic stressors such as negative energy, protein, and calcium balance associated with parturition and the onset of lactation may play a role in the loss of immune cell function observed around parturition, although these effects have not been clearly defined (Ropstad et al., 1989; Kehrli and Goff, 1989; Goff and Horst, 1997). If these stressors contribute to the degree of immune suppression experienced by the cow, they may also contribute to the progression of Johne's disease from a subclinical to a more clinical state in cows following the periparturient period. Typically, the periparturient dairy cow suffers a precipitous decline in DMI during the 2 to $3 \mathrm{~d}$ before calving and for a few days after calving (Hayirli et al., 2002). This contributes to the 
negative energy balance during this time and causes rapid mobilization of body fat. A previous study demonstrated that energy balance could be improved by forcefeeding periparturient cows (Bertics et al., 1992). This was accomplished by placing refused feed into the rumen in rumen-cannulated, pregnant cows. Using this approach, we were able to create periparturient cows with two different energy states. This study was designed to evaluate the effects of maintaining feed intake and thus improving energy balance during the periparturient period on the immune function of cows infected with Mycobacterium paratuberculosis.

\section{MATERIALS AND METHODS}

\section{Animals}

Twelve cows with paratuberculosis and in the last month of gestation were utilized in this study. Cows were Holstein $(\mathrm{n}=10)$, Brown Swiss $(\mathrm{n}=1)$, and Guernsey $(n=1)$. All cows were multiparous with parity ranging from 3 to 9 . The majority of the cows were already on site as part of the herd used by the Johne's disease research project. Additional cows that were purchased for the study were identified as naturally infected before purchase by serum antibody to $M$. paratuberculosis. These results were validated by an in-house ELISA performed in our laboratory. Cows were a mixture of subclinical $(\mathrm{n}=8)$ and clinical infection $(\mathrm{n}=4)$ as determined by fecal shedding of $M$. paratuberculosis and antibody titer. Subclinically infected cows shed low numbers of $M$. paratuberculosis ( $<10 \mathrm{cfu} / \mathrm{g}$ of feces) and were asymptomatic. Animals were classified as clinically infected on the basis of a high level of fecal $M$. paratuberculosis shedding (>100 cfu/g) and/or a high M. paratuberculosis-specific antibody titer. Clinical cows did not display typical signs of Johne's disease such as diarrhea or weight loss during the study. All cows were surgically fitted with rumen cannulas and allowed to recover at least 1 mo before initiation of the study. The four cows that were classified as clinical were allotted two per treatment group, but individual animals were assigned in a random manner. Average BW of cows was $689 \pm 22$ (range 603 to 762 ) and $742 \pm$ $46 \mathrm{~kg}$ (range 595 to 929 ) for control and stuffed cows, respectively. The Brown Swiss was allotted to the control group, and the Guernsey was allotted to the stuffed group. Body condition scores for all cows were good, ranging between 4 and 5 .

\section{Study Protocol}

The study period extended from 3 wk before calving to 3 wk postcalving. Control cows were offered feed at $2 \%$ of their individual BW, and orts were recorded daily.
Table 1. Ingredient composition and chemical analysis of precalving and postcalving diets on a DM basis.

\begin{tabular}{lcc}
\hline & \multicolumn{2}{c}{ Treatment } \\
\cline { 2 - 3 } Dietary ingredient, \% & Precalving & Postcalving \\
\hline Corn silage & 48.78 & 44.42 \\
Alfalfa hay & 15.34 & 13.97 \\
Ground corn & 11.28 & 10.27 \\
Beet pulp & 9.69 & 8.82 \\
Soychlor & 8.19 & - \\
Soyplus & 3.28 & 19.39 \\
Dicalcium phosphate & 0.81 & 0.73 \\
Calcium carbonate & 1.65 & 1.50 \\
Magnesium oxide & 0.36 & 0.33 \\
Trace mineral/vitamin mix $^{1,2}$ & 0.38 & 0.34 \\
Sodium chloride & 0.24 & 0.22 \\
Chemical analysis, ${ }^{3} \%$ & & \\
Ca & 1.38 & 1.29 \\
P & 0.45 & 0.47 \\
Na & 0.14 & 0.13 \\
K & 1.35 & 1.42 \\
Mg & 0.41 & 0.40 \\
Cl & 0.76 & 0.39 \\
S & 0.20 & 0.22 \\
\hline
\end{tabular}

${ }^{1}$ Provided $15 \mathrm{mg}$ of $\mathrm{Cu}, 60 \mathrm{mg}$ of $\mathrm{Zn}, 0.22 \mathrm{mg}$ of $\mathrm{Co}, 66 \mathrm{mg}$ of $\mathrm{Mn}$, $5 \mathrm{mg}$ of I, and $0.3 \mathrm{mg}$ of Se.

${ }^{2}$ Provided 100,000 IU of retinyl palmitate, 25,000 IU of vitamin $\mathrm{D}_{3}$, and $3,300 \mathrm{IU}$ of $\alpha$-tocopherol acetate.

${ }^{3}$ Means for diets: CP, $14.5 \%$; $\mathrm{ADF}, 22.2 \%$; NDF, $35.8 \%$; forage NDF, $27.2 \%$; NFC, $40.5 \%$; TDN, $70 \%$; $\mathrm{NE}_{\mathrm{L}}, 1.67 \mathrm{Mcal} / \mathrm{kg}$.

The stuffed group was also offered the same diet at $2 \%$ of their BW each day, but the orts were manually placed into the rumen 3 times per day, once at each feeding and one other time in the late evening. All cows were fed a corn silage-based diet with added ground corn, soybean meal, and alfalfa hay (Table 1) and randomly assigned in equal numbers to either treatment group (control or stuffed). All cows received an anion-supplemented diet before calving to minimize blood calcium changes. The postcalving diet did not contain the anion source, and the amount of expellers soybean meal was increased in the ration. For the $3 \mathrm{wk}$ after calving, all cows were offered $2.5 \%$ of their BW each day. Stuffed animals continued to have orts stuffed into their rumens 3 times per day.

\section{Sampling and Analyses}

Blood samples were obtained daily for 2 wk before and after calving for metabolic measurements such as NEFA, BHBA, glucose, 1, 25-dihydroxyvitamin $\mathrm{D}_{3}$, calcium, magnesium, and phosphorus. Blood and fecal samples were also obtained every 3 to $4 \mathrm{~d}$ for $3 \mathrm{wk}$ before calving and $3 \mathrm{wk}$ postcalving for other assays. Peripheral blood mononuclear cells from blood obtained in $2 \times$ acid-citrate-dextrose were isolated for lymphocyte proliferation and in vitro immunoglobulin assays on 
these sampling dates. Fecal samples were cultured for quantitative shedding of $M$. paratuberculosis.

\section{Metabolic Measurements}

Serum total calcium and magnesium concentrations were determined by atomic absorption spectrophometry (Perkin-Elmer Corp., 1965). Serum concentration of phosphorus was determined colorimetrically (Parekh and Jung, 1970). The NEFA concentrations were determined by an enzymatic-colorimetric method (Johnson and Peters, 1993), using a commercial kit (NEFA-C kit; WAKO, Saitama, Japan). The BHBA concentrations were determined by an enzymatic-colorimetric method (Williamson and Mellanby, 1974), with a commercial kit (Sigma beta-BHA kit \#310-A; Sigma, St. Louis, MO). Glucose concentrations were determined by an assay based on the Trinder reaction (Sigma kit \#315-100; Trinder, 1969). Colorimetric assays were performed in 96-well microtiter plates, and absorbance was read using a microplate reader (Thermomax Microplate Reader; Molecular Devices, Sunnyvale, CA). Serum 1,25-dihydroxyvitamin $\mathrm{D}_{3}$ concentrations were determined by competitive binding assay following isolation and partial purification by liquid chromatography (Horst et al., 1990).

\section{Culture of Feces}

Fecal samples were cultured for viable $M$. paratuberculosis for 12 wk on Herrold's egg yolk medium (HEYM) using the double decontamination-double centrifugation method as previously described (Stabel, 1997).

\section{Lymphocyte Proliferation}

Peripheral blood mononuclear cells (PBMC) were isolated from whole blood and plated at a density of $2 \times 10^{5}$ cells/well in triplicate in 96 -well tissue culture plates in culture medium (RPMI-1640 containing $25 \mathrm{mM}$ HEPES, $2 \mathrm{~m} M$ L-glutamine, penicillin G (200 U/ml), and streptomycin sulfate $(200 \mathrm{mg} / \mathrm{ml})$ containing $10 \%$ FBS (Stabel et al., 1993). Media for mitogenic stimulation contained $10 \mu \mathrm{g} / \mathrm{ml}$ of concanavalin A (ConA, Sigma), phytohemagglutinin (PHAP, Sigma), or pokeweed mitogen (PWM, Sigma). Optimal concentrations of each mitogen were previously evaluated by titration in our laboratory (Stabel et al., 1993). In addition, we chose these mitogen concentrations to correspond to the amount of $M$. paratuberculosis antigen $(10 \mu \mathrm{g} / \mathrm{ml})$ that was used to stimulate PBMC (data not shown). Plates were incubated for $72 \mathrm{~h}$ at $39^{\circ} \mathrm{C}$ in $5 \% \mathrm{CO}_{2}$, then $\left[{ }^{3} \mathrm{H}\right]$ methylthymidine $(5 \mu \mathrm{Ci} /$ well $)$ was added for an additional $18 \mathrm{~h}$. Cells were harvested on filtermats using a TomTec harvester (Tomtec, Orange, CT) and ${ }^{3} \mathrm{H}$ detected using a liquid scintillation counter (Wallac 1450 Microbeta Plus, Wallac, Gaithersburg, MD). Results were expressed as counts per minute.

\section{In Vitro Immunoglobulin Production}

Pokeweed mitogen-driven production of polyclonal immunoglobulin by lymphocytes was determined, as previously described (Stabel et al., 1991), by harvesting 12-d PBMC culture supernatants and assaying for IgM or IgG concentration $(\mu \mathrm{g} / \mathrm{ml})$ by ELISA. Culture supernatants, Ig standards, and control sera were diluted in carbonate buffer $(0.05 \mathrm{M}, \mathrm{pH} 9.6)$ and incubated overnight in a humidified atmosphere at $4^{\circ} \mathrm{C}$. After three consecutive washes with PBS containing $0.1 \%$ Tween 80 , plates were incubated for $30 \mathrm{~min}$ at $39^{\circ} \mathrm{C}$ with $1 \%$ gelatin to block nonspecific binding sites. Plates were then washed three times with PBS-Tween with 3-min soak periods between. After washing, plates were incubated with mouse anti-bovine Ig antibody (Sigma) for $1 \mathrm{~h}$ at $39^{\circ} \mathrm{C}$. Plates were washed three times in the same manner and incubated with anti-mouse Ig, biotinylated $\left.\mathrm{F}(\mathrm{ab})^{\prime}\right)^{2}$ fragment (Sigma), for $2 \mathrm{~h}$ at $39^{\circ} \mathrm{C}$. After washing, streptavidin biotinylated peroxidase complex (Amersham, Arlington Heights, IL) was added to each well and incubated for $30 \mathrm{~min}$ at $39^{\circ} \mathrm{C}$. Plates were washed one final time, and substrate solution (40 $\mathrm{mM}$ ABTS, 2,2'-azino-di-3-ethyl-benzthiozoline-6-sulphonic acid in citrate buffer, $\mathrm{pH}$ 4.0) was added for a 10-min incubation at room temperature. Serum containing known concentrations of IgM or IgG was included in each test run as positive controls. Absorbance at $405 \mathrm{~nm}$ was measured with an MR7000 plate reader (Dynatech, Chantilly, VA). The amount of Ig in samples was calculated by comparison with the absorbance of standards within a linear curve fit.

\section{Neutrophil Function Assays}

Procedures for measuring neutrophil chemotaxis and iodination (nmoles $\mathrm{Na}^{125}$ I per $10^{7}$ neutrophil per hour) were previously described (Kehrli et al., 1989b; Kimura et al., 2002).

\section{Statistical Analyses}

Data were analyzed by repeated measures using PROC MIXED procedure of the Statistical Analysis System (SAS Inst., Inc., Cary, NC). The model included the fixed effects of treatment (control vs. stuffed), day (time around parturition), and treatment $\times$ day interaction, the random effect of cows nested within treatment, and the residual error. For each variable analyzed, cow 
Table 2. Dry matter intake (kg of feed/100 kg BW per day) for cows assigned to the control group or stuffed group. Cows assigned to the stuffed group received additional TMR by manually stuffing their rumens with refuse feed to maintain DMI of $2 \% \mathrm{BW} / \mathrm{d}$ during the precalving period and $2.5 \% \mathrm{BW} / \mathrm{d}$ at calving and during the postcalving period. ${ }^{1}$

\begin{tabular}{lll}
\hline & \multicolumn{2}{c}{ Period of intake } \\
\cline { 2 - 3 } Treatment & Precalving & Postcalving \\
\hline Control & $1.24 \pm 0.10$ & $1.49 \pm 0.12$ \\
Stuffed & $1.92 \pm 0.04$ & $2.16 \pm 0.07$ \\
\hline
\end{tabular}

${ }^{1}$ Dry matter intake for the precalving and postcalving days was averaged for each animal before calculation of treatment means. Precalving represents days less than 1 and postcalving represents days greater than 0 . Data are expressed as means $\pm S E M ; n=6$.

nested within treatment was subjected to three covariance structures: compound symmetry, autoregressive order 1 , and unstructured covariance. The covariance that resulted in the Akaike's information criterion closest to zero was used. In all cases it was the autoregressive order 1 covariance structure. Means and SEM are reported for all data. When significant effects $(P<0.05)$ due to treatment, day, or treatment $\times$ day interactions were detected, means separation was conducted by the Tukey-Kramer option in SAS. Data were also split into two periods: before calving (days equal to or less than 1) and after calving (days greater than 0 ). Data analyses were conducted as described above for the two periods to determine significant effects.

\section{RESULTS}

Parturition did not affect fecal shedding status of the cows in this study. Two of the four cows that were actively shedding $M$. paratuberculosis in their feces $(<10 \mathrm{cfu} / \mathrm{g})$ before the study continued to shed the bacteria in similar amounts during the 3 wk postpartum. However, the remaining two cows (one in each treatment group) that were shedding before parturition (10 to $50 \mathrm{cfu} / \mathrm{g}$ ) began to shed 10 -fold more bacteria into their feces after calving. Interestingly, parturition did not induce shedding in a majority of the subclinically infected cows after calving regardless of dietary treatment. Only one cow that had not shed any $M$. paratuberculosis in her feces in the $3 \mathrm{wk}$ before calving began to shed at calving ( $13 \mathrm{cfu} / \mathrm{g}$ ), and this cow was in the control group. General health of cows in the study was good, with no incidence of displaced abomasum, ketosis or milk fever. All cows gave birth to single calves, and only one case of retained placenta was noted. Four cows (three control; one stuffed) demonstrated some evidence of mastitis that required treatment.

Dry matter intake (kg of feed/100 kg BW/d) for cows during the precalving and the postcalving periods is shown in Table 2. Stuffed cows had significantly $(P$
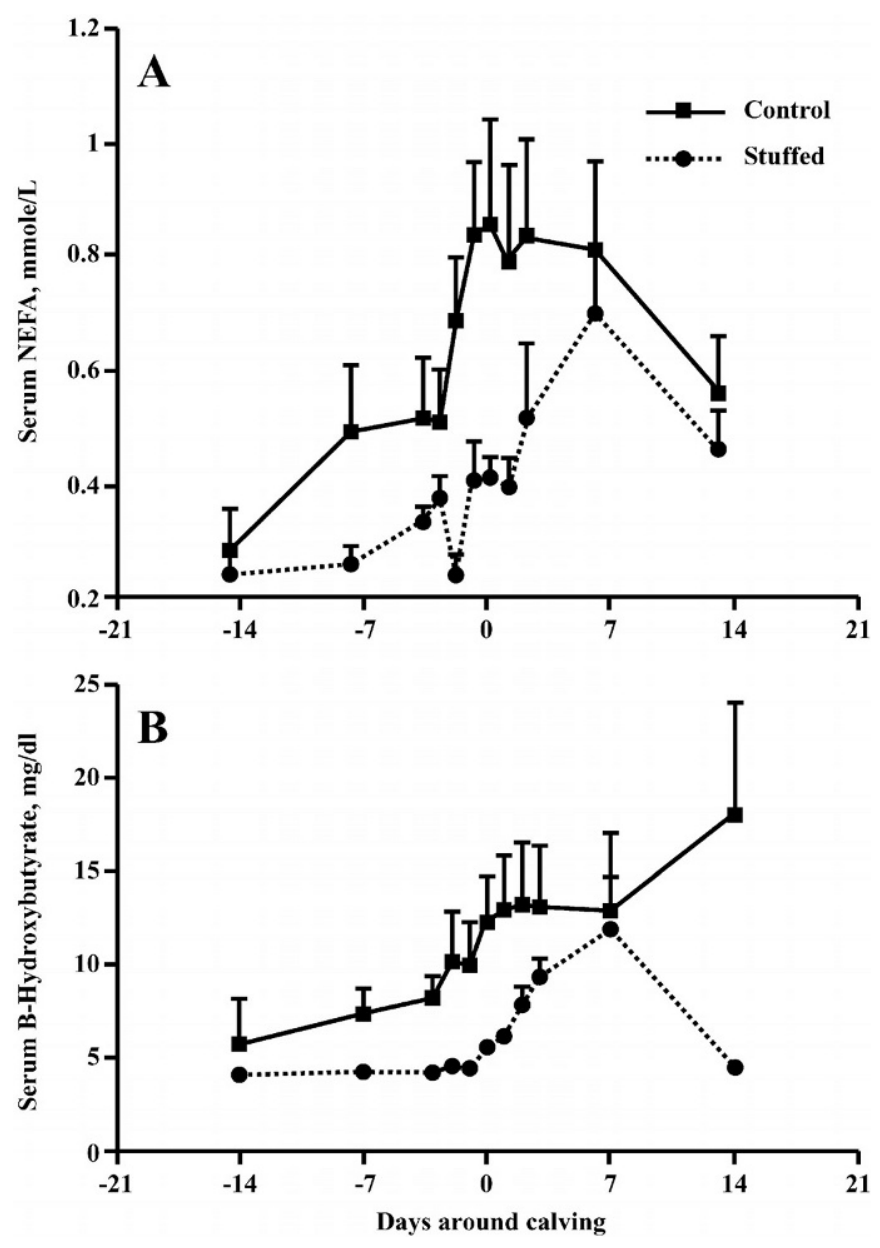

Figure 1. Effect of energy supplementation during 2 wk before calving and $2 \mathrm{wk}$ following calving on serum nonesterified fatty acid concentrations (A; NEFA; mmole/L) and serum BHBA (B; mg/dl). Treatment groups are cows receiving the basal diet (controls) and cows receiving the basal diet plus additional feed via their rumen cannulas (stuffed). Values shown are means \pm SEM; $n=6$.

$<0.01$ ) higher DMI than control cows throughout the periparturient period. There were no significant effects due to day or treatment $\times$ day interactions on DMI.

Across the experimental period, mean serum NEFA concentrations for stuffed cows $(0.40 \mathrm{mmole} / \mathrm{L})$ were significantly $(P<0.01)$ lower than in control cows $(0.60$ mmole/L) (Figure 1A). Serum NEFA concentrations were affected by time around parturition $(P<0.01)$ with serum levels increasing sharply at or shortly after calving in all cows. When data obtained during the precalving period were examined, there was a significant $(P<0.03)$ treatment $\times$ day interaction in serum NEFA levels. Serum NEFA increased precalving to a greater degree in control cows than in stuffed cows. Significant differences $(P<0.02)$ between stuffed $(4.45$ $\mathrm{mg} / \mathrm{dl})$ and control $(9.35 \mathrm{mg} / \mathrm{dl})$ cows were observed for BHBA in the precalving analysis with a significant $(P$ 


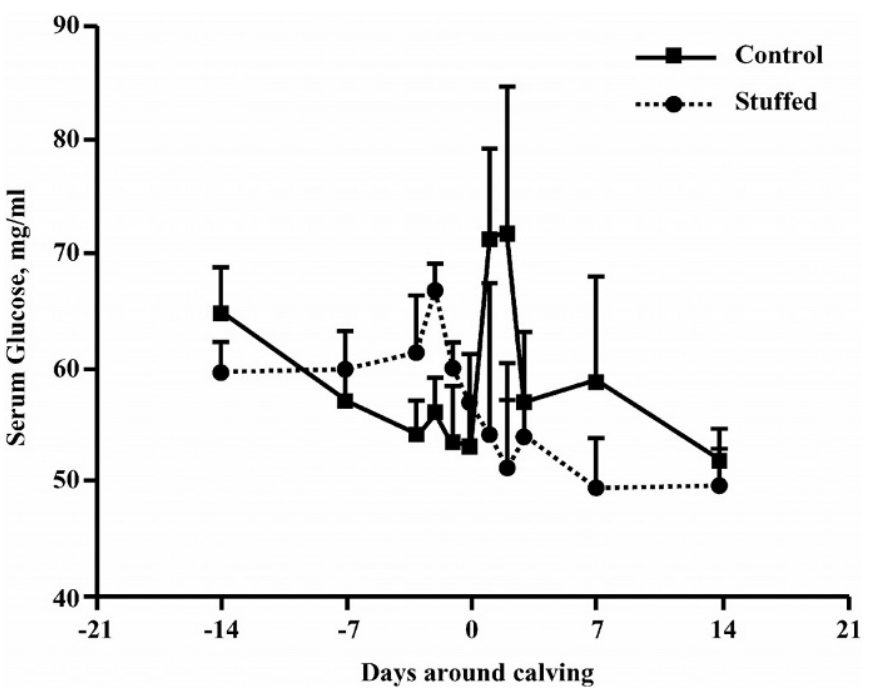

Figure 2. Effect of energy supplementation during 2 wk before calving and 2 wk following calving on serum glucose concentrations (mg/dl). Treatment groups are cows receiving the basal diet (controls) and cows receiving the basal diet plus additional feed via their rumen cannulas (stuffed). Values shown are means \pm SEM; $n=6$.

$<0.01)$ day effect noted for the precalving period as well (Figure 1B). Glucose levels in the serum were not significantly different between treatments when analyzed across the entire periparturient period. However, a significant $(P<0.05)$ day effect was noted in the precalving period, with reduced serum levels observed in the days right before calving (Figure 2). A significant $(P<0.05)$ treatment effect was noted in the postcalving period with higher serum glucose levels $(65.14 \mathrm{mg} / \mathrm{dl})$ noted for control cows than for stuffed cows (51.29 $\mathrm{mg} / \mathrm{dl})$.

Providing additional feed resulted in higher ( $8.40 \mathrm{vs.}$ $7.89 \mathrm{mg} / \mathrm{dl} ; P<0.05)$ serum calcium and higher magnesium levels $(2.14$ vs. $1.81 \mathrm{mg} / \mathrm{dl} ; P<0.01)$ for stuffed cows compared with control cows during the periparturient period (Figure 3A and B). Average serum calcium concentrations remained above $7.5 \mathrm{mg} / \mathrm{dl}$ in all cows throughout the periparturient period. No significant day effect or treatment $\times$ day interaction was observed in serum calcium. Although serum 1,25-dihydroxyvitamin $\mathrm{D}_{3}$ concentrations rose $(P<0.05$; day effect $)$ in all cows around the time of parturition, there were no significant treatment effects during the study, and treatment $\times$ day interactions were significant $(P<0.05)$ only when data collected in the precalving period were analyzed separately (days less than 0; Figure 4). There were no significant effects on serum phosphorus concentrations during the study (data not shown).

During the 3 wk pre- and postpartum, a marked decline and rebound $(P<0.001)$ in neutrophil iodination
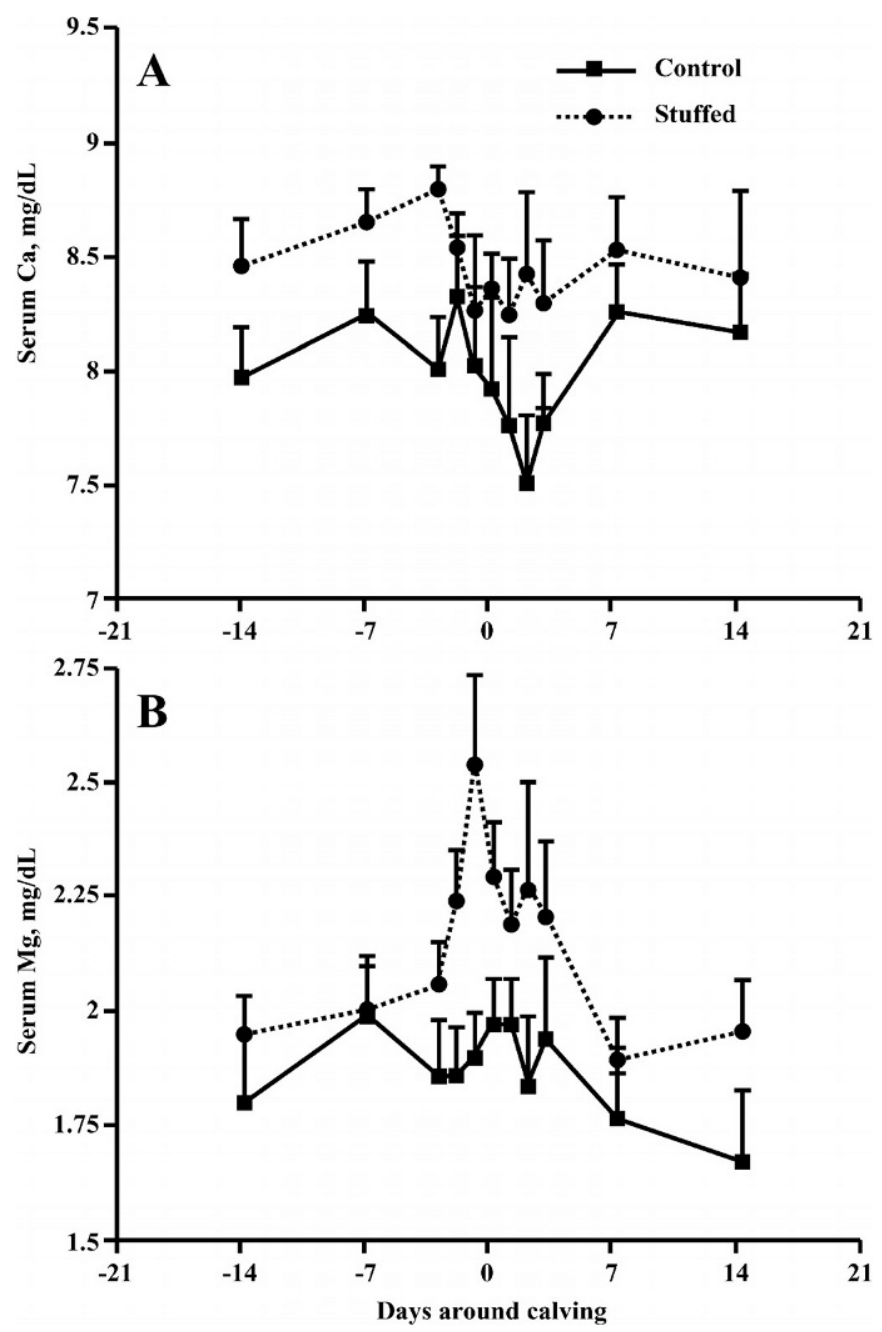

Figure 3. Effect of energy supplementation during 2 wk before calving and 2 wk following calving on serum calcium (A; Ca) and serum magnesium (B; $\mathrm{Mg}$ ) concentrations $(\mathrm{mg} / \mathrm{dl})$. Treatment groups are cows receiving the basal diet (controls) and cows receiving the basal diet plus additional feed via their rumen cannulas (stuffed). Values shown are means $\pm \mathrm{SEM} ; \mathrm{n}=6$.

activity was noted in both treatment groups (Figure 5). Providing additional feed did not alleviate the decline in neutrophil iodination activity in stuffed cows compared with control cows. No significant effects were noted on neutrophil chemotaxis between the two groups (data not shown).

Interestingly, there were significant treatment effects on $\mathrm{T}$ cell-mediated immune responses that were suppressed by energy supplementation. Control cows had significantly higher lymphocyte proliferation responses to all $\mathrm{T}$ cell mitogens across the study; ConA $(66,254$ vs. $35,502 \mathrm{cpm} ; P<0.001)$, PHAP (67,951 vs. $31,945 \mathrm{cpm}, P<0.002)$, and PWM $(46,465$ vs. 16,421 cpm, $P<0.01)($ Figure 6A/B/C). A significant increase 


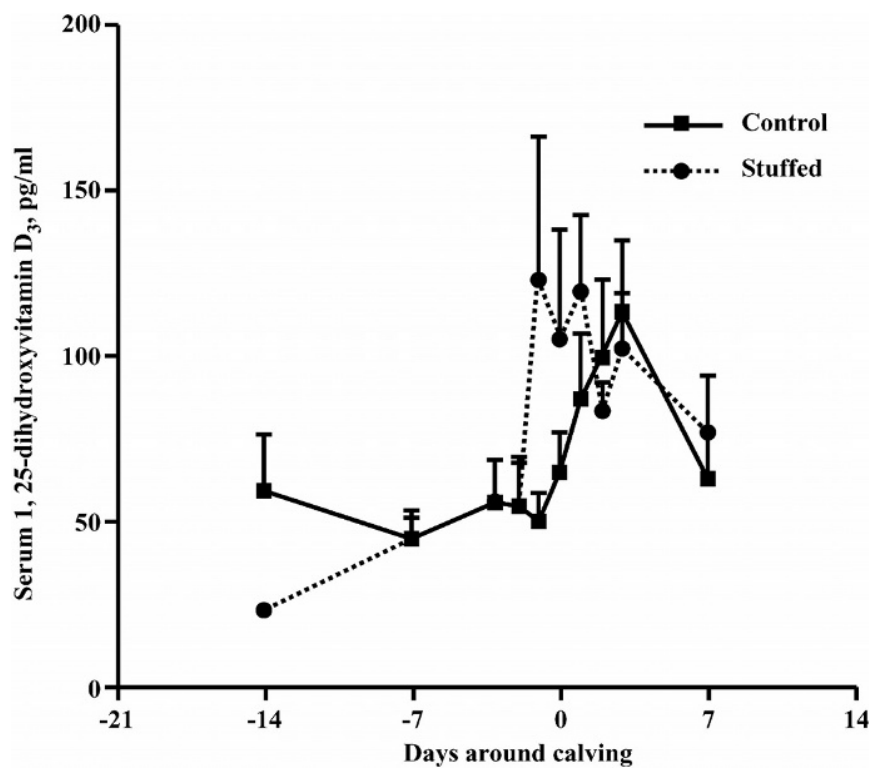

Figure 4. Effect of energy supplementation during 2 wk before calving and 2 wk following calving on serum 1, 25-dihydroxyvitamin $\mathrm{D}_{3}$ concentrations $(\mathrm{pg} / \mathrm{ml})$. Treatment groups are cows receiving the basal diet (controls) and cows receiving the basal diet plus additional feed via their rumen cannulas (stuffed). Values shown are means \pm $\mathrm{SEM} ; \mathrm{n}=6$

in proliferative responses was observed after calving for PBMC stimulated with ConA $(P<0.04$; day effect $)$ but no significant treatment $\times$ day interaction was

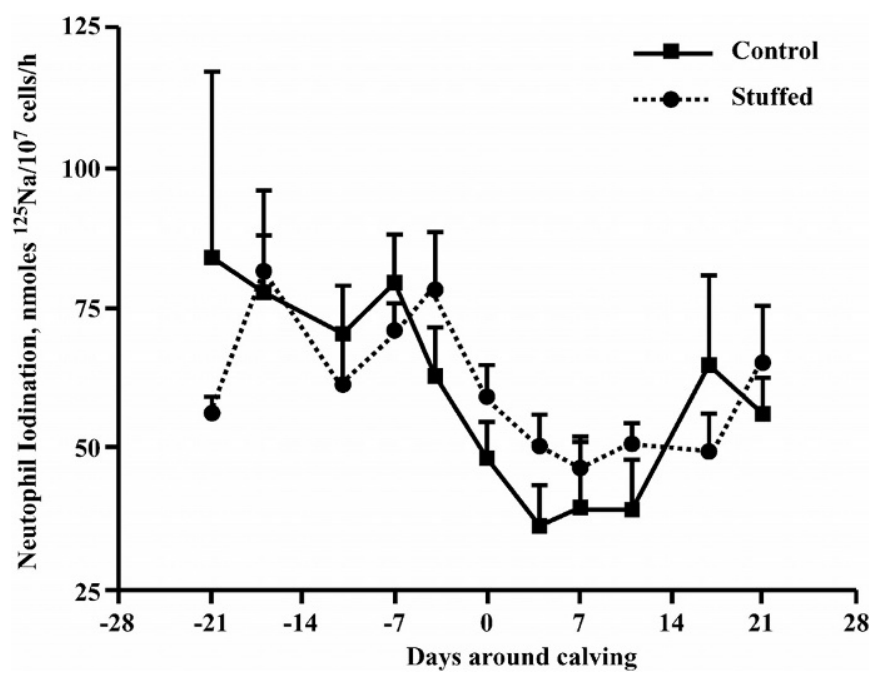

Figure 5. Effect of energy supplementation during 3 wk before calving and $3 \mathrm{wk}$ following calving on neutrophil iodination (nmoles ${ }^{125} \mathrm{NaI} / 10^{7} \mathrm{PMN} / \mathrm{h}$ ). Treatment groups are cows receiving the basal diet (controls) and cows receiving the basal diet plus additional feed via their rumen cannulas (stuffed). Values shown are means \pm SEM; $\mathrm{n}=6$.
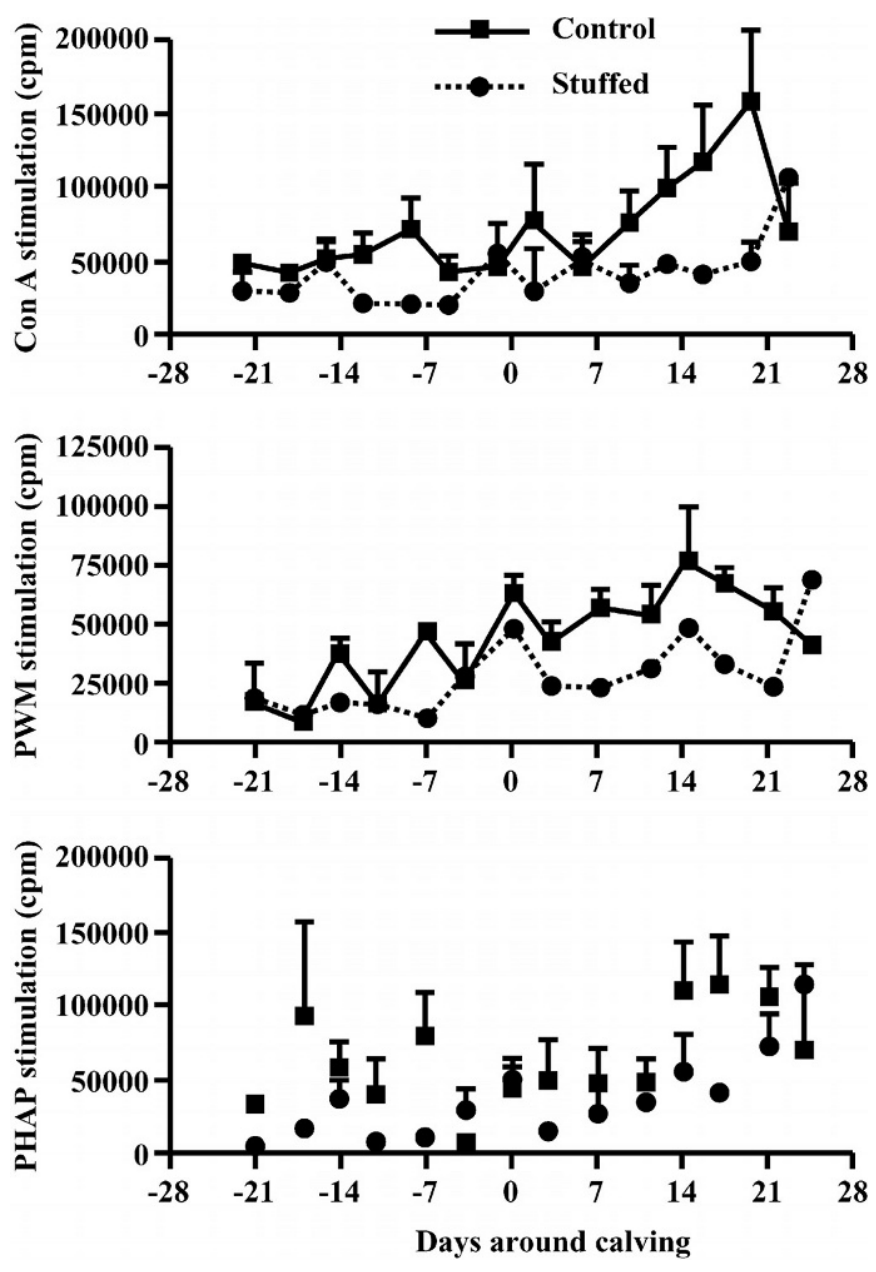

Figure 6. Effects of energy supplementation during 3 wk before calving and 3 wk following calving on lymphocyte proliferative responses (counts per minute) to concanavalin A (A; ConA), pokeweed mitogen (B; PWM) and phytohemagluttin-P (C; PHAP). Treatment groups are cows receiving the basal diet (controls) and cows receiving the basal diet plus additional feed via their rumen cannulas (stuffed). Values shown are means \pm SEM; $n=6$.

noted. No significant treatment effects were noted in PWM-driven IgM production when data were analyzed across the entire study (Figure 7A). However, differences in levels of secreted IgG in culture supernatants yielded a significant $(P<0.05)$ treatment $\times$ day interaction in the period after calving (Figure 7B). On d 21, in vitro IgG was significantly $(P<0.03)$ higher for stuffed cows than control cows.

\section{DISCUSSION}

Preventing the typical decline in DMI observed in periparturient cows by stuffing orts into their rumens resulted in reduced serum NEFA levels, suggesting that these cows maintained a more positive energy balance 

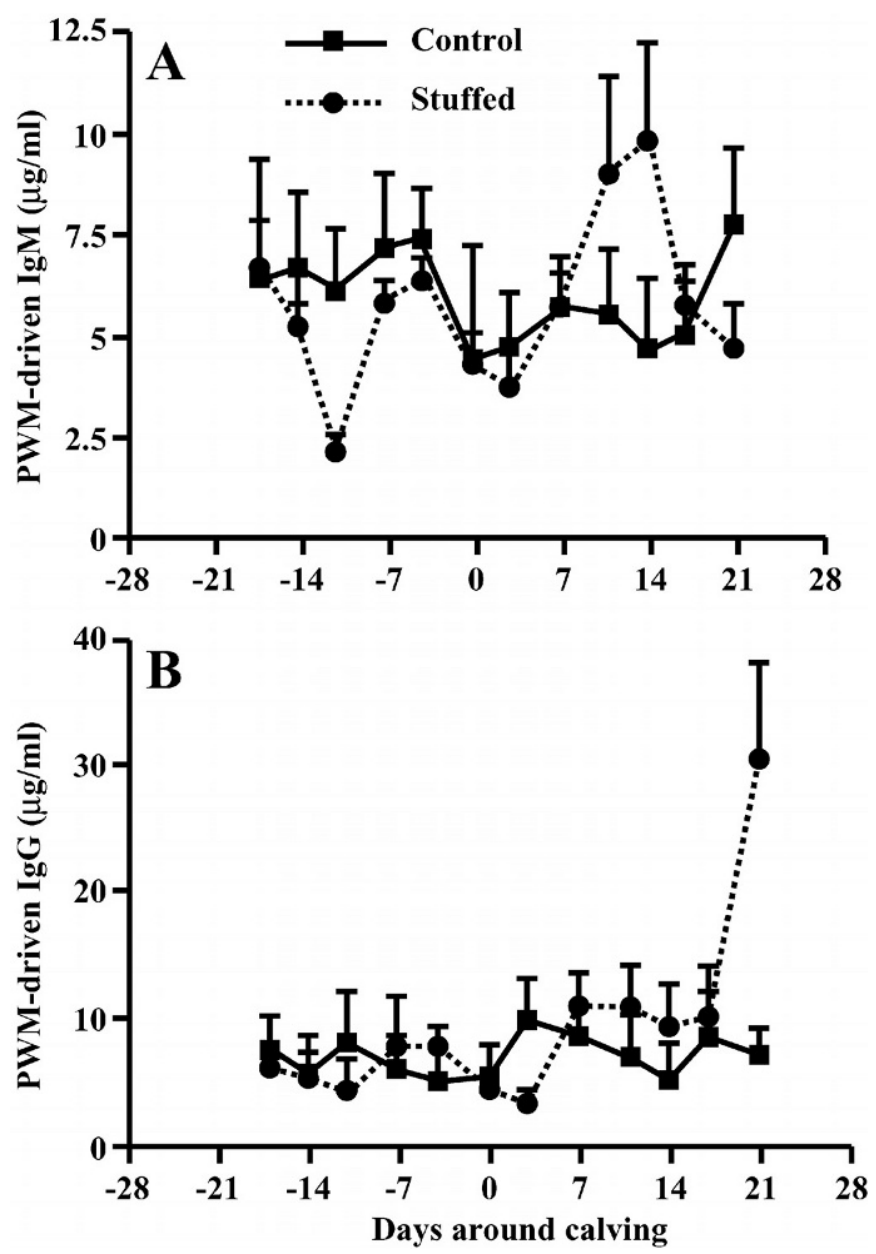

Figure 7. Effect of energy supplementation during 3 wk before calving and 3 wk following calving on in vitro immunoglobulin $\mathrm{M}$ and $\mathrm{G}$ concentrations (IgM, IgG; ng/ml). Treatment groups are cows receiving the basal diet (controls) and cows receiving the basal diet plus additional feed via their rumen cannulas (stuffed). Values shown are means $\pm \mathrm{SEM} ; \mathrm{n}=6$.

compared with the control cows. It has previously been shown that decreased DMI and negative energy balance associated with parturition or feed restriction results in increased concentrations of NEFA in the serum (Bertics et al., 1992; Perkins et al., 2001). Doepel et al. (2002) found that feeding a high-energy diet during the periparturient period could attenuate the increase in serum NEFA but not BHBA. Stuffing cows also improved calcium status, possibly by ensuring adequate intake of anions to maintain an acidotic state in these cows at the time of calving. Stuffing cows may have also insured that the intake of calcium and magnesium was not allowed to decrease at calving, which suggests that decreased DMI contributes to decreased blood calcium, often observed at parturition. Previously, it was demonstrated that mastectomized periparturient cows could maintain their serum calcium, whereas intact cows suffered hypocalcemia at calving, suggesting that lactation resulted in a significant drain in calcium for the cow (Goff et al., 2002). Preventing hypocalcemia may have a multitude of benefits for the cow including improvement in metabolic disorders, udder health, and general immunosuppression associated with parturition (Curtis et al., 1983; Oetzel, 1996).

The effects of energy supplementation on immune cell function in this study are interesting and novel. Stuffing did not alleviate the typical periparturient decline in neutrophil function that has been observed by others (Kehrli et al., 1989b); however, these are the first blood neutrophil data documented in periparturient cows with paratuberculosis. The role of neutrophils as a first defense against many invasive pathogens has not been thoroughly investigated for paratuberculosis since it is thought that $M$. paratuberculosis is largely engulfed by macrophages upon entry through the Peyer's patches (Momotani et al., 1986). It has also been demonstrated that neutrophil populations are significantly lower in the intestinal tissue of cows infected with $M$. paratuberculosis compared with noninfected controls (Lee et al., 2001). The dearth in neutrophils in the tissue may be due to signaling errors preventing neutrophils from localizing at the site of $M$. paratuberculosis colonization. Chronic inflammation may also have resulted in apoptotic events reducing numbers of neutrophils. Regardless, neutrophils are major defenders against IMI associated with mastitis (Kehrli et al., 1989b; Cooray and Hakansson, 1995). Although we hypothesized that energy supplementation during the periparturient period would enhance neutrophil function, the results of this study disproved this supposition.

Detrimental effects on lymphocyte proliferative responses by PBMC after stimulation with T-cell mitogens were noted in cows receiving additional feed with effects most distinct between 10 and $14 \mathrm{~d}$ postcalving. In contrast, energy supplementation appeared to increase the in vitro immunoglobulin production in stuffed cows, suggesting a switch in responsive cell type during this period. It has been well documented that T-cell mediated immunity shifts from Th-1 to Th-2 responses during pregnancy (Raghupathy, 1997; Sacks et al., 1999). This was recently demonstrated in a study evaluating shifts in the CD4+ subpopulations during the postpartum period (Shafer-Weaver et al., 1999). They documented that CD4+-enriched $\mathrm{T}$ cell populations isolated from the bovine had significantly greater expression of IL-4 and IL-10 within $3 \mathrm{~d}$ postpartum. By the mid- to late-lactation periods, these cows had reverted to Th1-type responses with higher expression of IFN- $\gamma$ in the CD4+ T cell population. Although cytokines were not measured in the present study, improving energy bal- 
ance of the cows by providing additional feed did result in an apparent increase in polyclonal antibody production after calving. This is an interesting observation, as the stimulation of polyclonal B cells is triggered by activated Th-2 cells (Lohoff et al., 1992).

In other periparturient studies, lymphocyte proliferative activity returned to prepartum levels within 5 to $8 \mathrm{~d}$ after calving (Saad et al., 1989; Ropstad et al., 1989). Our results show a protracted return to normal activity, indicating that $M$. paratuberculosis infection may further delay the rebound response of lymphocytes after calving and that energy supplementation is beneficial in reducing the time period until responses are normalized in infected animals.

\section{CONCLUSIONS}

Stuffing cows with additional feed resulted in a positive energy balance during the periparturient period, as indicated by reduced serum NEFA and BHBA levels. Energy supplementation of dairy cows depressed cellular immune function and appeared to enhance in vitro immunoglobulin production. Because of the shift from Th-1- to Th-2-mediated immunity associated with gestation, it seems plausible that the additional energy succeeded in amplifying the Th-2 response typically observed shortly after parturition. Because it is hypothesized that the progression of paratuberculosis from a subclinical to a clinical state is allayed by cell-mediated immunity, it is unclear whether supplemental energy during the periparturient period would be beneficial for $M$. paratuberculosis-infected cows. This is particularly true of those cows that are in a clinical state of disease since this stage is associated with reduced cell-mediated immunity and greater humoral immunity.

\section{ACKNOWLEDGMENTS}

The authors wish to thank Trudy Bosworth, Chad Reinke, and Arlen Andersen for excellent technical assistance. We also acknowledge Donnie Robinson and Tim Gogerty for their care of the animals.

\section{REFERENCES}

Bertics, S. J., R. R. Grummer, C. Cadorniga-Valino, and E. E. Stoddard. 1992. Effect of prepartum dry matter intake on liver triglyceride concentration and early lactation. J. Dairy Sci. 75:19141922.

Cooray, R., and L. Hakansson. 1995. Defective polymorphonuclear neutrophil function in dairy cows showing enhanced susceptibility to intramammary infections. Zentralbl. Vet. 42:625-632.

Doepel, L., H. Lapierre, and J. J. Kennelly. 2002. Peripartum performance and metabolism of dairy cows in response to prepartum energy and protein intake. J. Dairy Sci. 85:2315-2334.
Goff, J. P., and R. L. Horst. 1997. Physiological changes at parturition and their relationship to metabolic disorders. J. Dairy Sci. 80:1260-1268.

Guidry, A. J., M. J. Paape, and R. E. Pearson. 1976. Effects of parturition and lactation on blood and milk cell concentrations, corticosteroids and neutrophil phagocytosis in the cow. Am. J. Vet. Res. 37:1195-1200.

Hayirli, A., R. R. Grummer, E. V. Nordheim, and P. M. Crump. 2002. Animal and dietary factors affecting feed intake during the prefresh transition period in Holsteins. J. Dairy Sci. 85:34303443.

Horst, R. L., T. A. Reinhardt, and B. W. Hollis. 1990. Improved methodology for the analysis of plasma vitamin D metabolites. Kidney Int. Suppl. 29:S28-S35.

Johnson, M. M., and J. P. Peters. 1993. Technical note: An improved method to quantify nonesterified fatty acids in bovine plasma. J. Anim. Sci. 71:753-756.

Kehrli, M. E., Jr., and J. P. Goff. 1989. Periparturient hypocalcemia in cows: Effects on peripheral blood neutrophil and lymphocyte function. J. Dairy Sci. 72:1188-1196.

Kehrli, M. E., Jr., B. J. Nonnecke, and J. A. Roth. 1989a. Alterations in bovine peripheral blood lymphocyte function during the periparturient period. Am. J. Vet. Res. 50:215-220.

Kehrli, M. E., Jr., B. J. Nonnecke, and J. A. Roth. 1989b. Alterations in bovine peripheral blood neutrophil function during the periparturient period. Am. J. Vet. Res. 50:207-214.

Kehrli, M. E., Jr., J. L. Burton, B. J. Nonnecke, and E. K. Lee. 1999. Effects of stress on leukocyte trafficking and immune responses: Implications for vaccination. Adv. Vet. Med. 41:61-81.

Kimura, K., J. P. Goff, M. E. Kehli, Jr., and T. A. Reinhardt. 2002. Decreased neutrophil function as a cause of retained placenta in dairy cattle. J. Dairy Sci. 85:544-550.

Lee, H., J. R. Stabel, and M. E. Kehrli, Jr. 2001. Cytokine gene expression in ileal tissues of cattle infected with Mycobacterium paratuberculosis. Vet. Immunol. Immunopathol. 82:73-85.

Littell, R. C., P. R. Henry, and C. B. Ammerman. 1998. Statistical analysis of repeated measures data using SAS procedures. J. Anim. Sci. 76:1216-1231.

Lohoff, M., A. Koch, and M. Rollinghoff. 1992. Two signals are involved in polyclonal B cell stimulation by T helper type 2 cells: A role for LFA-1 molecules and interleukin 4. Eur. J. Immunol. 22:599-602.

Momotani, E., D. L. Whipple, A. B. Thiermann, and N. F. Cheville. 1986. Role of M cells and macrophages in the entrance of Mycobacterium paratuberculosis into domes of ileal Peyer's patches in calves. Vet. Pathol. 25:131-137.

Parekh, A. C., and D. H. Jung. 1970. Serum inorganic phosphorus determination using p-phenylenediamine as a reducing agent. Clin. Chem. Acta 27:373-377.

Perkin-Elmer Corp. 1965. Analytical methods for atomic absorption spectrophotometry. Perkin-Elmer Corp., Norwalk, CT.

Perkins, K. H., M. J. VandeHaar, R. J. Tempelman, and J. L. Burton. 2001. Negative energy balance does not decrease expression of leukocyte adhesion or antigen-presenting molecules in cattle. J. Dairy Sci. 84:421-428.

Raghupathy, R. 1997. Th1-Type immunity is incompatible with successful pregnancy. Immunol. Today 18:478-482.

Ropstad, E., H. J. Larsen, and A. O. Refsdal. 1989. Immune function in dairy cows related to energy balance and metabolic status in early lactation. Acta Vet. Scand. 30:290-219.

Saad, A. M., C. Concha, and G. Astrom. 1989. Alterations in neutrophil phagocytosis and lymphocyte blastogenesis in dairy cows around parturition. J. Vet. Med. B 36:337-345.

Sacks, G., I. Sargent, and C. Redman. 1999. An innate view of human pregnancy. Immunol. Today 20:114-118.

SAS. 1999. SAS User's Guide, Version 8.01. Statistical Analysis System Institute, Cary, NC.

Shafer-Weaver, K. A., C. M. Corl, and L. M. Sordillo. 1999. Shifts in bovine CD4+ subpopulations increase T-helper-2 cells compared with T-helper-1 effector cells during the postpartum period. J. Dairy Sci. 82:1696-1706. 
Stabel, J. R. 1997. An improved method for cultivation of Mycobacterium paratuberculosis from bovine fecal samples and comparison to three other methods. J. Vet. Diagn. Invest. 9:375-380.

Stabel, J. R., M. E. Kehrli, Jr., and J. P. Goff. 1993. Enhancement of lymphocyte function and interleukin $1 \beta$ transcription by recombinant bovine interleukin 1 $\beta$. Am. J. Vet. Res. 54:86-91.

Stabel, J. R., M. E. Kehrli, Jr., J. R. Thurston, J. P. Goff, and T. C. Boone. 1991. Granulocyte colony-stimulating factor effects on lymphocytes and immunoglobulin concentrations in periparturient cows. J. Dairy Sci. 74:3755-3762.
Trinder, P. 1969. Determination of blood glucose using an oxidaseperoxidase system with a non-carcinogenic chromogen. J. Clin. Pathol. 22:158-161.

Waller, K. P. 2000. Mammary gland immunology around parturition. Influence of stress, nutrition and genetics. Adv. Exp. Med. Biol. 480:231-245.

Williamson, D. H., and J. Mellanby. 1974. D-3-Butyrate. Page 1836 in Methods of Enzymatic Analysis. H. U. Bergmeyer, ed., Academic Press, London, UK. 